\title{
Author Index Vol. 40, No. 2-3, 1997
}

Aguzzi,A. 198Liebert,U.G. 176

Berger,J.R. $122 \quad$ Lipton, H.L. 143

Bode,L. 185 Loon, A.M. van 153

Brady, J.N. $132 \quad$ Ludwig, H. 185

Casas,I. 72 Lüke,W. 112

Ceresa,D. 85 Major, E.O. 98

Cinque, P. 85 Marenzi, R. 85

Cleator, G.M. $62 \quad$ Martinez-Martin, P. 72

Echevarría, J.M. 72 Muir,P. 153

Frey,T.K. 167 Nath,A. 122

Jelachich, M.L. 143 Petry, H. 112

Kitze,B. 132 Weber, Th. 59,98,198

Klapper,P.E. 62

KÀRCER (C) 1997 S.KargerAG, Basel 213

Fax+ 41613061234 E-Mail karger@karger.ch www.karger.com 